\title{
The role of hydrographic parameters, measured from a ship of opportunity, in bloom formation of Karenia mikimotoi in the English Channel
}

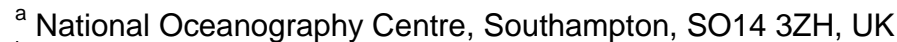 \\ ${ }^{b}$ DYNECO-Physed, Ifremer, Centre de Bretagne, BP 70, 29280 Plouzané, France
}

\begin{abstract}
:
Unusually high chlorophyll values ( $14 \mathrm{mg} \mathrm{chl} \mathrm{m}^{-3}$ at $5 \mathrm{~m}$ depth), recorded on a ship of opportunity (SOO) in July 2010, indicated the occurrence of a potential Harmful Algal Bloom (HAB) in the Western approaches of the English Channel. This bloom, located at $49.7^{\circ} \mathrm{N}, 3.2^{\circ} \mathrm{W}$ was observed via complementary datasets. These included data from samples collected for microscopic phytoplankton identification, information from satellite maps to follow geographical bloom development and in situ data to identify hydrographic factors related to bloom initiation. The relationships between chlorophyllfluorescence, temperature, salinity and wind speed were examined. The intense summer bloom predominantly consisted of the dinoflagellate Karenia mikimotoi and followed an increase in sea surface temperature (to $18.5^{\circ} \mathrm{C}$ ). A mid-channel bloom of this magnitude along the SOO route was last seen in 2003. In both years the peak biomass was associated with Karenia mikimotoi blooms, which occurred at the same location and coincided with the least saline, warmest water and lowest wind speeds. This study demonstrates that ships of opportunity are a useful tool to identify and track $\mathrm{HAB}$ events through continuous in situ measurements and for the frequent sampling opportunities that they provide.
\end{abstract}

Keywords : Karenia mikimotoi ; Harmful Algae ; wind speed ; temperature ; low salinity water ; French Atlantic rivers ; English Channel ; Ferry-box

\section{Introduction}

Intense, spatially restricted summer phytoplankton blooms are common in the western English Channel (Pingree et al., 1977; Holligan et al., 1984; Jordon \& Joint, 1984; Irigoein et 
al., 2004; Brand et al., 2012). The bloom magnitude varies year to year and can exceed 100 mg Chl $a \mathrm{~m}^{-3}$ (Kelly-Gerreyn et al., 2006; Garcia-Soto \& Pingree, 2009). They generally occur between $48^{\circ} \mathrm{N}$ and $50^{\circ} \mathrm{N}$ and are dominated by the 'red-tide' forming dinoflagellate Karenia mikimotoi (previously identified as Gyrodinium aureolum) in most years. This species is ecologically significant in the western English Channel contributing up to $47 \%$ of the total annual primary production (Holligan et al., 1983). However, environmental concerns have been raised associating it with fish kills and water column anoxia (Tangen, 1977, Satake et al., 2005; Gentien et al., 2007); for example fish kills off the southern Irish coast (Raine et al., 2001; Silke et al., 2005). Consequently, Karenia mikimotoi can be considered a Harmful Algal Bloom (HAB) species; its many physiological and environmental characteristics have been reviewed (Dahl and Tangen, 1993; Gentien et al., 2007; Gowen et al., 2008; Brand et al., 2012).

In a simplified view of phytoplankton bloom development bloom events are controlled by a combination of temperature, light and nutrients, which are in turn driven by physical processes (Behrenfield et al., 2006). Although summer blooms are studied extensively the controls on their timing and intensity are less well understood (Brand et al., 2012). Blooms of Karenia mikimotoi have been observed in the Bay of Brest (Morin et al., 1989) with the first appearance of cells in May and population increases in stratified stable conditions. In the Western English Channel Karenia mikimotoi blooms dominate in conditions of decreased wind and increased sea surface temperatures (Garcia-Soto \& Pingree, 2009). Likewise Widdicombe et al., (2010) linked intense Karenia mikimotoi dominated blooms, of 2 to 5 week duration, to warm stratified conditions at the L4 site in the English Channel. The Karenia mikimotoi cells are fragile and slow growing, however they may have a competitive advantage over other species through diel migration and allelopathic affects (Brand et al., 2012). The development of large Karenia mikimotoi blooms is a function of both biological factors and physical factors such as mixing (Davidson et al., 2009; Brand et al., 2012). Although presently no single group of factors can account for the sporadic spatiotemporal distribution of these blooms and a predictive mechanistic model has not been developed (Brand et al. 2012).

The effects of climate change on the succession of phytoplankton functional groups are generally unknown, especially with respect to potential increases in temperature (Gollop et al., 2007; Brand et al., 2012; Fu et al., 2012). In the Irish Sea Harmful Algal Blooms are increasing in frequency (Raine et al., 2001; Gowen et al., 2008). Should species composition 
move toward more toxic or nuisance species there will be important implications for fisheries and public health (Widdicombe et al., 2010). It is thought that increasing temperature may influence the timing of summer blooms enhancing the growth of dinoflagellate species, such as Karenia mikimotoi; the mechanism of enhanced stratification favouring motile species (Falkowski \& Oliver, 2007). In the Western English Channel there has been a $0.5^{\circ} \mathrm{C}$ warming over the past 50 years (Smyth et al., 2010). This is seen at the L4 site in the English Channel where dinoflagellate blooms are now starting to occur later in the summer than has been previously reported (Widdicombe et al., 2010).

There is currently a gap in knowledge in tracking the mid Channel HAB blooms (as distinct from coastal blooms), identifying the dominant species and seeing how they are influenced by the hydrography. In this study we investigate the summer dinoflagelate blooms in the western English Channel in 2010. The extent of the bloom is mapped using satellite data whilst discrete samples, taken from a ferry platform, identified Karenia mikimotoi as the dominant species in the mid July bloom. We examine the spatial and temporal variability of chlorophyll-fluorescence in relation to hydrographic measurements made from Ship Of Opportunity (SOO) operation using a Ferry-box (Hydes et al., 2003; Bargaron et al., 2006; Kelly-Gerreyn et al., 2006; Hartman et al., 2013). A 'time series' extracted from the Ferrybox dataset in the English Channel $\left(49.7^{\circ} \mathrm{N}, 3.4^{\circ} \mathrm{W}\right)$ provides temporal coverage at the peak of the Karenia mikimotoi bloom while spatial context is provided by satellite data. In situ data includes cell counts, species identification and direct measurements of salinity and oxygen. We also consider the role of meteorological and tidal factors on the intensity of potentially harmful Karenia mikimotoi phytoplankton blooms in the Western English Channel.

\section{Materials and methods}

\subsection{Area of study}

Fig. 1 shows the idealised route of the Pride of Bilbao (PoB) ferry (P \& O European Ferries Ltd) operating between Portsmouth (UK, $50.8^{\circ} \mathrm{N}, 1.1^{\circ} \mathrm{W}$ ) and Bilbao (Spain, $43.4^{\circ} \mathrm{N}$, $3.0^{\circ} \mathrm{W}$ ). The ship made approximately two crossings each week (except for January when the ship was in refit). The northbound tracks are almost identical from month to month and provide consistent data for inter-comparison. In Fig. 1 the route is divided topographically into regions 1-8 following Bargeron et al., (2006). In this paper we focus on complementary datasets from the Western English Channel $\left(48^{\circ} \mathrm{N}\right.$ to $\left.50^{\circ} \mathrm{N}\right)$, particularly in the summer 
stratified region 3. The stratification parameter (S) was used to distinguish regions 2 to 4 in the Western English Channel (after Pingree \& Griffith, 1978).

\subsection{Bloom identification}

The location of the summer bloom was identified using a MODIS ocean colour map of chlorophyll in the western English Channel during July 2010; provided by Plymouth Marine Laboratory. Further maps were used to show the progression of the bloom; chlorophyll for these maps were derived from a merged MERIS/MODIS OC5 product from Ifremer. Sea surface temperature, from OSTIA UK Met Office products, was also extracted and mapped for three successive dates.

The ferry was used as a platform for sample collection, discrete water samples being collected along the route by scientific personnel at approximately monthly intervals. Sampling was maintained around the clock in both north and southbound transects. Water samples collected for phytoplankton identification and counting by light microscopy were preserved in $100 \mathrm{ml}$ darkened bottles with $2 \%$ Lugol's solution. Sub-samples settled in $100 \mathrm{ml}$ settling chambers for 24 hours and were examined using an inverted microscope. Large and numerically rare taxa were counted during full examination of the settling chamber (at x100), while small and numerically dominant taxa were counted on 1 to 2 transects of the chamber (x400) or from cumulative counts of 5 to 10 fields of view. Diatoms and dinoflagellates were identified to genera or species levels. The identification of the species Karenia mikimotoi was confirmed using a molecular biology method similar to a polymerase chain reaction (PCR), nucleic acid sequence based amplification (Ulrich et al., 2010).

Water samples from the ferry were also filtered and analysed ashore using High Performance Liquid Chromatography (HPLC) for phytoplankton pigments (reported in Smythe-Wright et al., 2014). Additionally on day 203 (July $22^{\text {nd }}$ ), two samples of water were collected by the Environmental Health and Pollution Regulation Unit seven miles to the west of Guernsey; these were sent to CEFAS Lowestoft for species identification using microscopy and cell counts, using a similar method to the one used for samples collected from the ferry.

\subsection{Data from the Ferry-Box}

The ferry was instrumented with a Ferry-box system from April 2002 until the closure of the route in 2010. Each transect measured $\sim 1000 \mathrm{~km}$ with a journey time of about 35 
hours each way, giving a repeat sampling frequency varying from 4 hours to 3 days depending on location. The design and operation of the PoB Ferry-box system was detailed in Hydes et al., (2003) and in Kelly-Gerreyn et al., (2006). In brief the instrument was connected to the ship's cooling water supply which takes water from a depth of $5 \mathrm{~m}$ and the flow rate through the system was 15 to $201 \mathrm{~min}^{-1}$.Chlorophyll-fluorescence (precision $0.01 \pm$ $0.01 \mathrm{mg} \mathrm{Chl} \mathrm{m}^{-3}$ ) was measured using a Turner C3 sensor. The Turner C3 was calibrated by directly comparing its fluorescence values to samples of High Performance Liquid Chromatography (HPLC) measured chlorophyll-a. During the Karenia mikimotoi bloom, in the middle of July 2010, the conversion of chlorophyll-fluorescence to chlorophyll-a was: chlorophyll-a $=0.0041$ x fluorescence units $+0.1603\left(\mathrm{r}^{2}=0.91\right)$. The Turner C3 instrument also provides turbidity and coloured dissolved organic matter fluorescence (CDOM) readings. Bio-fouling of the optical sensor was controlled through the use of a mechanical wiper on the Turner C3 instrumentation. Additionally all sensors were cleaned on a weekly basis to reduce bio-fouling, when the ship was in port (Portsmouth). Oxygen (precision 0.1 umol $\mathrm{l}^{-1}$ ), temperature (precision $0.003^{\circ} \mathrm{C}$ ) and conductivity (precision $0.005 \mathrm{mmho} \mathrm{cm}^{-1}$ ) were measured using Aanderra sensors.

Data were logged at rates between 5 and 30 seconds on a National Oceanography Centre, Southampton (NOC) designed logging and control system. Download of the data occurred once a week. Public domain Matlab routines (http://marine.csiro.au/ morgan/seawater) provided the calculations for salinity and density; these were based on UNESCO (1983) algorithms. Hovmöller plots were used to show the spatial and temporal variation of Ferry-box data on the repeat ferry routes north of $48^{\circ} \mathrm{N}$ (Ushant) from day 40 to 250 ( $\left(9^{\text {th }}\right.$ February to $7^{\text {th }}$ September). We then extracted a time series at a single latitude corresponding to the location of the summer bloom as identified by the satellite maps and cell counts, $49.7^{\circ} \mathrm{N} 3.4( \pm 0.06)^{\circ} \mathrm{W}$. The time series runs from day 150 (30th May) to day 250 ( 7 th September) to cover the time of the summer phytoplankton bloom in 2010 .

\subsection{Meteorological, tidal and model tidal data}

The daily tidal range was computed from an English Channel Model (ECH-18HC, http://www.pol.ac.uk/appl/supply.html). It was computed from high and low water times and heights obtained from the nearest location to the time series: $49.7^{\circ} \mathrm{N}, 3.4^{\circ} \mathrm{W}$. The UK Met office provided hourly wind speed and wind direction data from sensors deployed on an 
automatic weather station in the English Channel at $49.9^{\circ} \mathrm{N}, 2.9^{\circ} \mathrm{W}$. Daily solar radiation data were obtained from the National (USA) Centre for Environmental Prediction (NCEP) (http://iridl.ldeo.columbia.edu/SOURCES/.NOAA/.NCEP-NCAR/.CDAS-1/) using the reanalysis products available online. From these sources data were extracted at $49.7^{\circ} \mathrm{N}$, $3.4^{\circ} \mathrm{W}$ to coincide with the 'time series' site and wind stress was calculated (Josey, et al., 2002).

A 3D hindcast numerical model (Lazure et al., 2009) was used to answer questions about stratification. The model used a Northeast Atlantic basin model as a boundary condition for salinity and climatological values for river discharge. Information on the thermocline was generated from the 3D model using the difference between surface and bottom temperature as a proxy of stratification.

\section{$3 \quad$ Results}

\subsection{Occurrence of the bloom}

The location of the summer bloom is illustrated in Fig. 2 using an ocean colour map of chlorophyll in the western English Channel during July 2010. This figure also shows the track of the Pride of Bilbao $(\mathrm{PoB})$ ferry, which was used as a sampling platform for taking discrete water samples during the three day return crossings between Portsmouth and Bilbao. The other sampling locations mentioned in this paper (L4, E1 and Guernsey) are also highlighted in Fig. 2. The satellite image (Fig. 2) clearly shows the intense summer bloom in the mid western English Channel during July 2010 that peaked on day 196 (15th July 2010). The image was produced from MODIS data, whereas further weekly composite maps in Fig. 3 were produced from MERIS/MODIS composites (and used a slightly different colour scale). Figure 3 clearly shows the progression of the bloom to the east with time from day 190 ( $9^{\text {th }}$ July) towards the island of Guernsey on day 202 (21st July). Sea surface temperature maps (Fig. 3) indicate the evolution of derived satellite sea surface temperature (SST) data over the same period of time; they show a high temperature signal throughout the bloom period but especially at the start of the bloom on the $9^{\text {th }}$ July.

Cell counts from the discrete samples taken from the Ferry-box platform are shown on a $\log$ scale in Fig. 4. This figure shows the results from a single crossing from Portsmouth to Bilbao, Spain (12 to 15th July 2010). The figure demonstrates that Karenia mikimotoi is the dominant bloom species from $49.8^{\circ} \mathrm{N}\left(2.9^{\circ} \mathrm{W}\right)$ to $49.27^{\circ} \mathrm{N}\left(4.08^{\circ} \mathrm{W}\right)$ in the north western English Channel with cell concentrations reaching over 700,000 cells $1^{-1}$. The cell counts from 
samples taken in Guernsey on the 22nd July (day 203) showed 934,000 and 1380000 cells $1^{-1}$ of Karenia mikimotoi, 24000 and 9000 cells $1^{-1}$ of pseudo-nitzschia sp, and 200 cells $1^{-1}$ of dinophysis sp in one of the samples (Gohin et al., 2010).

The Hovmöller plots in Fig. 5a to Fig.5d are used to show spatial and temporal variations in the Ferry-box data from the repeat transects in the north of the ferry route (from Ushant at $48^{\circ} \mathrm{N}$ to Portsmouth at $\left.51^{\circ} \mathrm{N}\right)$ and from day 40 to $250\left(9^{\text {th }}\right.$ Feb to $7^{\text {th }}$ Sept 2010$)$. The chlorophyll-fluorescence data in Fig. 5a shows the temporal and spatial development of the Karenia mikimotoi bloom, with exceptionally high chlorophyll- fluorescence values between day 190 ( $9^{\text {th }}$ July) and day 200 (19 ${ }^{\text {th }}$ July).

Day to day variation is seen more clearly in the time series from the Ferry-box data in Figures 6a to 6f. Ferry-box chlorophyll-fluorescence data (Fig. 6a.) suggests an earlier start date for the bloom than captured by weekly composite images (Fig. 3), at around $11^{\text {th }}$ July (day 192). At the peak of the bloom on day 196 (15 ${ }^{\text {th }}$ July) chlorophyll concentrations reached $14 \mathrm{mg} \mathrm{m}^{-3}$ (Fig. 6a). Figure 6a shows that the bloom lasted 18 days until the $21^{\text {st }}$ July (day 202), with a secondary bloom around the $29^{\text {th }}$ July (day 210) which coincides with the satellite imagery.

Oxygen was introduced to the Ferry-box suite of sensors from 2005 as an indicator of phytoplankton productivity. The Hovmöller plot in Fig. 5b shows that oxygen saturation peaks around day 170 (19th June) before the main peak in chlorophyll-fluorescence in July 2010. However from the time series figures the large increase in chlorophyll on the 15th July (day 196), was not reflected by an exceptional peak in the oxygen signal (Fig. 6b) which seems disproportionally small. There was a short lived peak of higher oxygen saturation (Fig. 6b) on 19th July (day 200), just after the bloom. Oxygen saturation increased around 29th July, (day 210) when the chlorophyll values suggest a secondary peak in the bloom (Fig. 6b). Turbidity and CDOM readings from the C3 sensor are further indicators of phytoplankton growth. However the peak values in CDOM and turbidity are seen towards the end of the bloom period (Fig. 6c).

\subsection{Temperature \& salinity}

We present sea surface temperature from satellites (Fig. 3) and 5m Ferry-box data (Fig. 5c and 6d). An offset is expected in the data, due to the different depths measured. Intercomparison of the temperature sensors is beyond the scope of this paper but each dataset is internally consistent and is used to show the spatial and temporal variations in the sea surface 
(and $5 \mathrm{~m}$ ) water temperature. In both the satellite and Ferry-box datasets the surface water temperature between $49^{\circ} \mathrm{N}$ and $50^{\circ} \mathrm{N}$, shows a general increase through the summer peaking on the $16^{\text {th }}$ July, (day 197) just prior to the summer bloom.

The close relationship between temperature and density is seen in Fig. 6d. There was a brief dip in density values just prior to the July bloom (Fig. 6d) and the lowest value was seen on the $12^{\text {th }}$ July (day 193, 1025). Density increased slightly just after the peak of the bloom on $19^{\text {th }}$ July, (day 200, 1026.2) then decreased as the short lived bloom broke up. Following the bloom there were further periods of decreased density, which can be linked to the smaller secondary bloom events around $29^{\text {th }}$ July (day 210 ).

The Hovmöller plot (Fig. 5d) shows pulses of relatively low salinity (35) into the channel, north of $48.5^{\circ} \mathrm{N}$. This is seen around day 85 (26 $6^{\text {th }}$ March) until day 195 (14 $\left.4^{\text {th }} \mathrm{July}\right)$, at the start of the bloom. From the time series the salinity minima on the $12^{\text {th }}$ June, (day 163 , salinity 34.9) does not coincide with the peak of the bloom at $49.7^{\circ} \mathrm{N}$ and salinity shows a small increase just prior to the bloom (Fig. 6e). Noise in salinity is related to the variation in longitude between the north and south bound routes in this time series (order of 0.6 degrees longitude). The increase in salinity is linked to a period of reduced noise and is seen from around the $9^{\text {th }}$ July (day 190) to $31^{\text {st }}$ July (day 212) at the time of the bloom, suggesting a more homogenous surface signal.

Fig. 7 shows collated Hovmöller plots of temperature, salinity and oxygen saturation along the Ferry-box route north of $48^{\circ} \mathrm{N}$, from 2003 to 2010 . It shows a year to year variation in low salinity signal in the channel (north of $49.5^{\circ} \mathrm{N}$ ). Lower salinity and increased temperature values are seen in the summers of both 2003 and 2010 at this latitude. Dissolved oxygen values are particularly high at this location in summer 2010. Dissolved oxygen data are not available before 2005 .

\subsection{Meterological \& tidal data}

The tidal cycles shown (Fig. 6e) suggest that the July 2010 fluorescence peak follows high spring tides, (peaking on the $12^{\text {th }}$ July, day 193).

NCEP (National Centre for Environmental Prediction) data extracted at the nearest point to $49.7^{\circ} \mathrm{N}, 3.4^{\circ} \mathrm{W}$ show an increase in solar radiation (Fig. 6f) from $13^{\text {th }}$ (day 194) to $17^{\text {th }}$ July, (day 198). This is over the period of the Karenia mikimotoi bloom. Wind stress is relatively low up to the occurrence of the bloom and peaks at the start of the bloom on day $196\left(15^{\text {th }}\right.$ July, Fig. 6f $)$, when the wind was predominantly to the northwest. 


\section{Discussion}

\subsection{Occurrence of the bloom}

In this paper we show new results to describe the July 2010 phytoplankton bloom in the Western English Channel. Sampling from the ferry at the peak of the bloom identifies the dominance of Karenia mikimotoi at this time. Previous studies have reported frequent occurrences of Karenia mikimotoi as the dominant species in the stratified northern shelf area of the western English Channel during summer (Pingree et al., 1975; Holligan et al., 1984). This species is well adapted to frontal regions there (Le Corre et al., 1993; Smayda, 2002).

The summer blooms can be identified using satellite data (Garcia-Soto \& Pingree, 2009; Gohin et al., 2010). Satellite images can also show the movement of the bloom and in this study they showed that the bloom moved to the southeast of the ferry track by the week of the $22^{\text {nd }}$ of July. A disadvantage in using just satellite data is that Karenia mikimotoi blooms may develop as a thin layer at the pycnocline and these subsurface blooms will not be detected (Brand et al., 2012). Also there is a potential mismatch between satellite and chlorophyll-a in situ measurements due to CDOM interference (Blondeau-Patissier et al., 2004). The duration of the bloom cannot be resolved with 8 day resolution satellite data composites so remote sensing cannot resolve patchiness in English Channel waters.

Sampling is needed to identify the species and the ferry was used as a platform for sampling the water. Species composition was confirmed by microscopic examination of samples collected on the crossing that coincided with the peak of the bloom. The cell counts showed that the mid July bloom in 2010 , occurring between $49.2^{\circ} \mathrm{N}$ to $49.8^{\circ} \mathrm{N}$, was predominantly Karenia mikimotoi. The cell counts for Karenia mikimotoi are three orders of magnitude higher than the other species. It would appear that they augment a dinoflagellate bloom consisting mostly of Procentrum sp. and Ceratium sp.

Ferry-box chlorophyll-fluorescence data could be of use to the satellite community for calibration purposes and can detect the bloom when the satellites fail due to day to day changes in atmospheric conditions. The Ferry-box chlorophyll-fluorescence data clearly indicated surface expression of a short, intense phytoplankton bloom in the English Channel during July 2010. In situ data also show that a secondary bloom formed by the $29^{\text {th }}$ July, when the ferry track passes to the north of the bloom.

Through 8 years of Ferry-box operation the only two years that a mid-channel occurrence of Karenia mikimotoi has been identified, through continuous measurements and 
monthly sampling for microscopic cell counts, are 2003 (Qurban, 2009) and 2010. The cell counts observed in 2010 were lower than previously reported for the Karenia mikimotoi dominated bloom in 2003 (when 8000,000 cells $1^{-1}$ were recorded, Qurban, 2009). This may be because the ferry track cuts into the edge of the bloom in 2010.

Monthly sampling at a relatively coastal site in the Western English Channel, E1 at $50.03^{\circ} \mathrm{N}, 4.37^{\circ} \mathrm{W}$, suggests that large blooms were seen each year from 2003 to 2005 (over 20,000 cells $1^{-1}$ Karenia mikimotoi, Claire Widdicombe, pers comm.), with relatively low counts from 2006 to 2008. Although cell counts were high at the E1 site in 2009 large summer blooms were not seen mid channel from the ferry route at that time. Also high oxygen saturation readings indicative of the Karenia mikimotoi blooms were seen in July 2010, but such high oxygen saturation was not seen in the Ferry-box data during other summers. Counts at the E1 sites are not available for 2010 however counts of Karenia mikimotoi were high at the more coastal L4 site. At the end of July 2010 cell counts of 158,000 cells $1^{-1}$ were recorded on the $26^{\text {th }}$ July 2010 (Claire Widdicombe, pers comm.). The coastal region experienced a later summer bloom than seen mid channel. This illustrates that the Karenia mikimotoi blooms are localised and care should be taken in extrapolating relatively coastal data into the mid channel region sampled by the Ferry-box.

In situ fluorometry, used for decades as an indication of chlorophyll-a, is subject to errors due to changes in phytoplankton physiological and community structure (Suggett et al., 2004). It is widely accepted that sensor measurements record only the fluorescent properties of seawater (and communities therein) and are not accurate values for chlorophyll-a concentrations (Falkowski \& Kiefer, 1985). Accuracy may be improved by calibrating fluorometers in situ although the calibration will only hold as long as the phytoplankton community remains constant which is unlikely to be true over extended time periods (Petihakis et al., 2007).

In the present study the Ferry-box fluorometer was calibrated at the time of the bloom event, using HPLC techniques to determine chlorophyll-a. This gives a robust indicator of the summer bloom event and confirms that chlorophyll-a values were in excess of $14 \mathrm{mg} \mathrm{m}^{-3}$. The HPLC data offered additional information on species composition through pigment markers. The Karenia mikimotoi bloom was associated with an increase in fucoxanthin and gyroxanthin-diester (Smythe-Wright et al., 2014), which may be used as a marker for some Karenia species (Brand et al., 2012).

Dissolved oxygen was added to the Ferry-box suite of sensors in 2005 as it is a useful 
indicator of productivity (Bargaron et al., 2006; Hydes et al., 2008). The increase in dissolved oxygen before the peak in chlorophyll-fluorescence in July 2010, is clearly seen in the Hovmöller plots. This may indicate expression of a subsurface bloom with oxygen diffusion to the surface in the absence of a surface chlorophyll signal from the Ferry-box or satellite datasets. Despite a series of relatively high surface oxygen concentrations the peak of the bloom was not associated with an exceptional peak in oxygen concentrations as had been expected. This may be because Karenia mikimotoi blooms have a high biological oxygen demand, when respiration within the bloom exceeds photosynthesis (Smayda, 2002; Vanhoutte-Brunier et al., 2008).

The calculation of new production from oxygen (as in Bargaron et al., 2006) would have resulted in a relatively low estimate of productivity compared with the cell numbers and chlorophyll concentrations due to the mis-match of oxygen and chlorophyll. This may suggest that the bloom is an advective feature. Alternatively it may indicate that the bloom is mixotrophic. Many studies suggest this species can assimilate organic substances especially dissolved organic nitrogenous compounds, and indicate the importance of heterotrophic nutrition among dinoflagellate species (Purina et al., 2004; Brand et al., 2012). These processes may all contribute to sustain Karenia mikimotoi growth without necessarily increasing the oxygen saturation.

Karenia mikimotoi is a motile species known to grow at the thermocline, an optimum depth between maximal nutrients and sufficient light for growth (Raine et al., 2001; Sharples et al., 2005; Ross \& Sharples, 2007) and there is some evidence for diel migration in a stable water column (Brand et al., 2012). Full depth data would be required to investigate this further although we suggest that surface measurements of dissolved oxygen could be used as an early indicator of these subsurface blooms before they are visible through satellite measurements. The oxygen data reported from the Ferry-box dataset suggests oxygen saturation of $120 \%$ in July 2010 which is in excess of the $110 \%$ suggested as indicative of large dinoflagellate blooms (Holligan et al., 1984). CDOM and turbidity are further indicators of phytoplankton growth available from the Ferry-box dataset. However in this study the peaks occurred towards the end of the bloom period suggesting an increase in organic material at the demise of the July 2010 bloom.

\subsection{Temperature and salinity data}

The July 2010 bloom was constrained between $49^{\circ} \mathrm{N}$ and $50^{\circ} \mathrm{N}$ where increased sea 
surface temperature $\left(18.5^{\circ} \mathrm{C}\right)$ was seen from the Ferry-box Hovmöller plots. This region of the Western English Channel is weakly stratified in spring and summer, with high surface temperature and a mixed layer depth ranging to between 15 to 30m (Pingree et al., 1977; Bargeron et al., 2006).

It is reasonable to attribute differences in chlorophyll concentrations between years, in part, to higher surface water temperatures in some summers. Qurban (2009) linked the 2003 Karenia mikimotoi bloom to relatively high SST from the Ferry-box SOO data $\left(16.8^{\circ} \mathrm{C}\right.$ at the time of the bloom compared with $15 \pm 0.3^{\circ} \mathrm{C}$ in the July of the previous and following years). Gomez \& Souissi, (2008) and Vanhoutte-Brunier et al., (2008) linked the 2003 bloom to the summer heat wave. Garcia-Soto \& Pingree (2009) also linked anomalously high satellite derived SST values to the 2003 bloom of Karenia mikimotoi.

Calm waters are an important prerequisite for Karenia mikimotoi to bloom (Gentien, 1998; Gentien et al., 2007). A link between well-established thermoclines and intense blooms of Karenia mikimotoi has been previously suggested (Pingree et al., 1977; Holligan et al., 1984). This species is also known to increase water temperature locally through absorption of shortwave radiation in the extensive blooms that form in shallow stratified layers (Jordan \& Joint, 1984).

The high resolution Ferry-box data was used to look at salinity as another factor which may influence the growth of Karenia mikimotoi. A salinity minimum was seen at the latitude associated with the Karenia mikimotoi bloom in July $2010\left(49.7^{\circ} \mathrm{N}\right)$. However the minima occurred a month earlier than the start of the bloom with a slight increase in salinity just prior to the bloom, possibly due to increased evaporation as the temperature increases. The bloom coincided with a decrease in density due to the high temperature and the relatively low salinity as seen from the Ferry-box data.

The annual salinity cycle in the Channel is for higher salinity in winter and lower salinity in summer (on account of the balance between rainfall, evaporation, river discharges and inflow of Atlantic waters; Pingree, 1980). However, an exceptionally low salinity signal is seen in some years due to the intrusion of low salinity surface water (LSSW) into the Channel, which is dependent on wind and tidal conditions as discussed in Kelly Gerreyn et al., (2006).

The present study suggests that the inter-annual variability in the intensity of the blooms of Karenia mikimotoi in this region may in part be related to the presence or absence of low salinity intrusions. Karenia mikimotoi has been associated with low salinity in river- 
derived buoyant waters along the Norwegian coast (Lindahl, 1993) and the French coast of the western English Channel (Videau et al., 1998). Low salinity and high temperatures will contribute to an increase in stratification and stability of the water column. Both of the years that have been associated with large mid channel summer bloom of Karenia mikimotoi (2003 and 2010) have the signature of LSSW just prior to the bloom. The summer blooms in both of these years are associated with lower density waters $\left(\right.$ rho $\left.<1025.7 \mathrm{~kg} \mathrm{~m}^{-3}\right)$.

Pingree (1980) showed that salinity is more important than temperature in determining the horizontal gradients in surface density (while temperature is more important in determining vertical density gradients in the English Channel). In 2003 the onset of the bloom was coincident with the arrival of the low salinity water, identified in the Ferry-box data set, coming from Ushant (Qurban, 2009). The effect of the low salinity intrusion on surface density in the western English Channel was investigated by Kelly Gerreyn et al., (2006) who found that 2003 was significantly fresher by 0.32 salinity and warmer by $1.95^{\circ} \mathrm{C}$ (compared to 2002), decreasing the surface density by $0.68 \sigma$-t and resulting in a more stratified water column. This would contribute favourable conditions for the observed intense summer algal bloom. Similar hydrographic conditions were seen in 2010 and contributed to the intense short lived Karenia mikimotoi bloom in July.

\subsection{Meteorological and tidal data}

Smayda (1997) suggests that dinoflagellate 'red tides' are often associated with a combination of intense rainfall, runoff and periods of intense irradiance. This forms lenses of freshened water, in an already stratified water column, in which the population can grow and avoid dispersal. In the present study NCEP data from 2010 was used to provide additional information on the meteorological conditions during summer bloom formation. The bloom event followed high solar irradiance and low wind stress over the preceding week. The increase in solar radiation will enhance growth of Karenia mikimotoi and the stable conditions required for growth. Gohin et al. (2010) routinely monitors the occurrence of summer dinoflagelate blooms using just SST, turbidity and chlorophyll from satellite data. They suggest that the high air temperature and solar irradiance were common characteristics in July in both 2003 and 2010. This could be linked to the development of Karenia mikimotoi blooms in these years.

There was a small peak in wind stress at the start of the summer bloom in 2010. This was unexpected, as it was thought that this would break up the stratification that is a 
prerequisite for growth of this species. However this relatively high wind stress should be taken in context as it is low compared with winter values in the channel. The westerly winds assisted advection of the bloom to the east and the bloom was tracked as far as Guernsey. Episodic pulses of wind deepen the thermocline and may entrain nutrients into the surface layer so short term wind events are important during the summer stratified period (Behrenfeld et al., 2006). However Karenia mikimotoi is a motile dinoflagellate, so can migrate to the thermocline for nutrient replenishment and increased nutrients may not necessarily be an advantage (Brand et al., 2012).

Tidal conditions have an influence on the stability of the water column in this seasonally stratified region. The Western English Channel thermally stratifies in spring and summer as the buoyancy forces of solar irradiance overcomes the capacity for tidal mixing to maintain a vertically homogeneous water column (Sharples, 2008). In July 2010 the neap tides were associated with peaks in oxygen concentrations in the time series data and relatively small chlorophyll-fluorescence peaks. The main Karenia mikimotoi bloom, as indicated by chlorophyll-fluorescence, followed a spring tide. The bloom had dispersed from the region by the neap tide. The bloom peak timing is in contrast to the suggestion that a neap tide period is necessary for summer blooms to develop in a stable water column (Holley \& Hydes, 2002; Sharples, 2008). Garcia-Soto \& Pingree (2009) related these summer blooms to low wind speed and a weakening tide developing just after the spring tide.

The tidal conditions are important on a larger scale as they influence fresh water supply into the Channel. The introduction of LSSW is dependent on certain wind and tidal conditions. If the arrival of French river waters at the Ushant Front coincides with north easterly winds and a spring tide then more LSSW is seen in the Western English Channel (Kelly-Gerreyn et al., 2006). South westerly wind conditions introduce Celtic sea water (Kelly Gerreyn et al., 2006). In 2003 and $2010 \mathrm{LSSW}$ was seen north of $49.5^{\circ} \mathrm{N}$ prior to the intense Karenia mikimotoi blooms in 2003 and 2010.

The 3D model was used to get a hind cast of stratification as the difference between surface and bottom water temperature in the middle of the channel (Fig. 8). The model shows the difference between surface and bottom temperature and density. The density difference includes the effect of salinity. However the difference in temperature is shown to be the major cause of density difference. Stratification output from the model suggests that 2010 is characterised by strong thermal stratification although stratification alone does not promote the occurrence of these large dinoflagellate blooms as a seed population is required 
(Smayda, 2002). We suggest that advection of the seed populations in the low salinity waters crossing the Ushant frontal region may contribute to larger blooms of Karenia mikimotoi in years such as 2003 and 2010.

The cause of the demise of the bloom in 2010 is unclear from the data available. The Karenia mikimotoi species still dominated when the bloom reached Guernsey (Gohin et al., 2010). It has been postulated that these blooms are short lived as they are disrupted by storm events or grazing. Storm events were not identified from the NCEP data. Likewise we cannot identify grazing from the data available. Some dinoflagellates exhibit an allelopathic defence against copepod predation (Smayda, 1997) and some copepods reject Karenia mikimotoi as food (Holligan et al., 1984; Uye and Takamatsu, 1990; Brand et al., 2012). However, it is beyond the scope of this paper to assess if Karenia mikimotoi is avoided by zooplankton or if Karenia mikimotoi is toxic to its potential predators.

\section{$5 \quad$ Conclusions}

The intense summer bloom of Karenia mikimotoi in 2010 was registered by in situ Ferry-box sensor measurements of chlorophyll-fluorescence and dissolved oxygen. Dissolved oxygen was a distinctive marker of the bloom prior to surface detection of chlorophyll through satellite or Ferry-box measurements. Species composition was confirmed through microscopy on samples collected from the ferry platform. The bloom followed a period of high temperature (following increasing solar irradiance) in the north west English Channel. This would have increased water stability and development of the thermocline. This was confirmed by model data that showed increased stratification in 2010 coinciding with the occurrence of the mid channel Karenia mikimotoi bloom. The 8 year Ferry-box 'time series' will need to be extended to determine if there is a trend towards increased occurrence of this species in a warming ocean.

While temperature may be the dominant factor determining the intensity of blooms of Karenia mikimotoi (warmer summers produce larger blooms) the start of the bloom was associated with the intrusion of low salinity water into the Channel. It is hypothesised that the presence of low salinity water may enhance blooms of Karenia mikimotoi through increased buoyancy of the upper water column. As the contribution of LSSW changes from year to year it may contribute to inter-annual variability in the occurrence of this dinoflagellate. The proposed hypothesis, that low salinity intrusions in the western English Channel enhance blooms of dinoflagellates through increased buoyancy, lends itself readily to testing with a 
coupled physical-ecosystem model.

\section{Acknowledgements}

This work has benefitted greatly from the help and service of the following people: Jon Campbell (NOC) for technical skills in setting up and maintenance of the Ferry-box system, various students for help on the calibration crossings, Clive Martin for helping to maintain the system and download the data onboard the ship. We thank the staff of P\&O European Ferries Ltd. Maureen Edwards (NOC) is thanked for designing and maintaining the Ferry-box web pages (http://www.soc.soton.ac.uk/ops/ferrybox_index.php). This work was supported by the European Commission under the 5th RTD Framework Programme, Contract $\mathrm{n}^{\circ}$ : EVK2-CT-2002-00144. A weekly composite satellite image was supplied by NEODAAS and we thank Peter Miller and Stelios Christodoulou (PML). Other chlorophyll images from Ifremer and OSTIA SST images have been provided through MyOcean. Cell count data was supplied by Diane Purcell (NOC) and Clare Widdicombe (PML). We thank the UK Met office for access to wind data from the buoy. Tidal data was supplied by Lisa Eastwood (NOC, Liverpool). We thank Simon Josey and Liz Kent (NOC) for useful discussion on the meteorological data. Thanks to Stephen Boswell (NOC) for chlorophyll-a calibration \& HPLC. Thanks to Boris Kelly-Gerreyn and two anonymous reviewers for comments on the text.

\section{Figures}




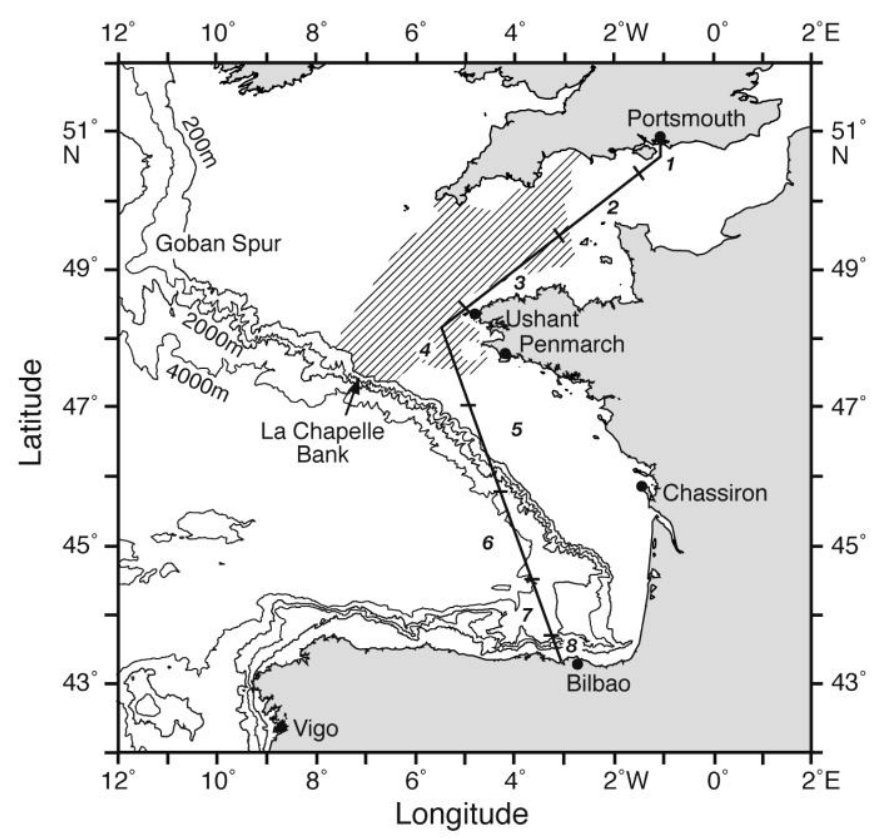

Fig. 1. Idealised Ferry route divided topographically into regions 1-8 following Bargeron et al., (2006). Of relevance are regions 2 (shallow, mixed 30-60m central channel, $\mathrm{S}<1$ ); 3 (shallow, summer stratified western channel) and 4 (the western approaches near the French coast at Ushant $(30-130 \mathrm{~m})$. The hatched area shows the extent of transitional values $(2>\mathrm{S}>$ 1) for the stratification parameter, S (Pingree \& Griffith, 1978).

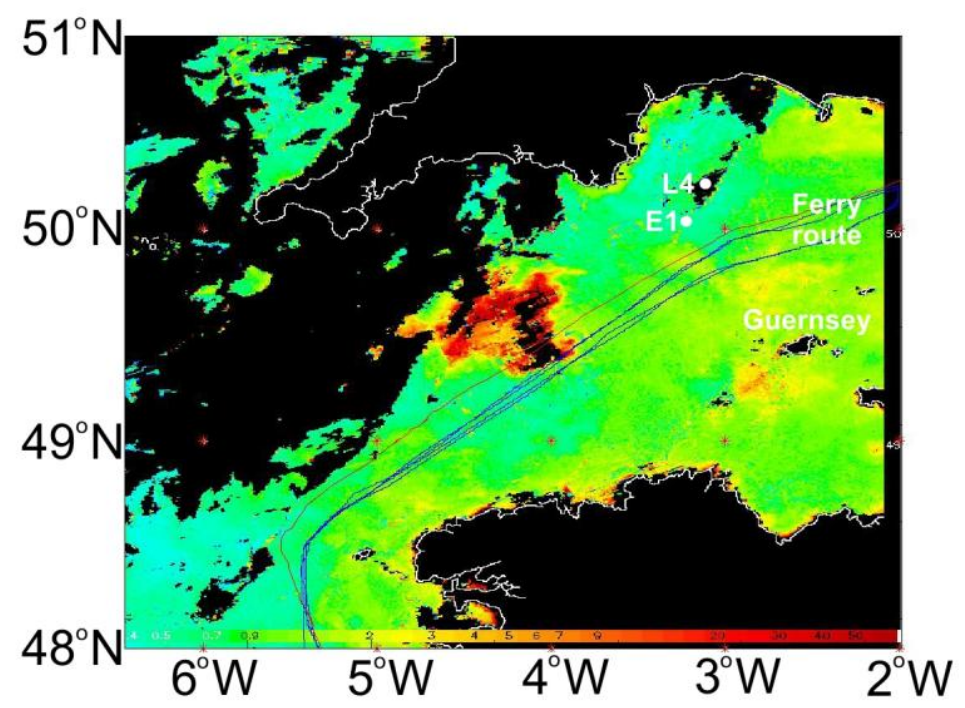

Fig. 2: The ferry route through a region of the channel for a period of 7 days following the $14^{\text {th }}$ of July (days $196-200$ ) overlaid on the MODIS median chlorophyll from $08^{\text {th }}$ to $14^{\text {th }}$ July at the time of the Karenia mikimotoi bloom when high chlorophyll readings were seen (in red) to the north and west of the ferry track. 

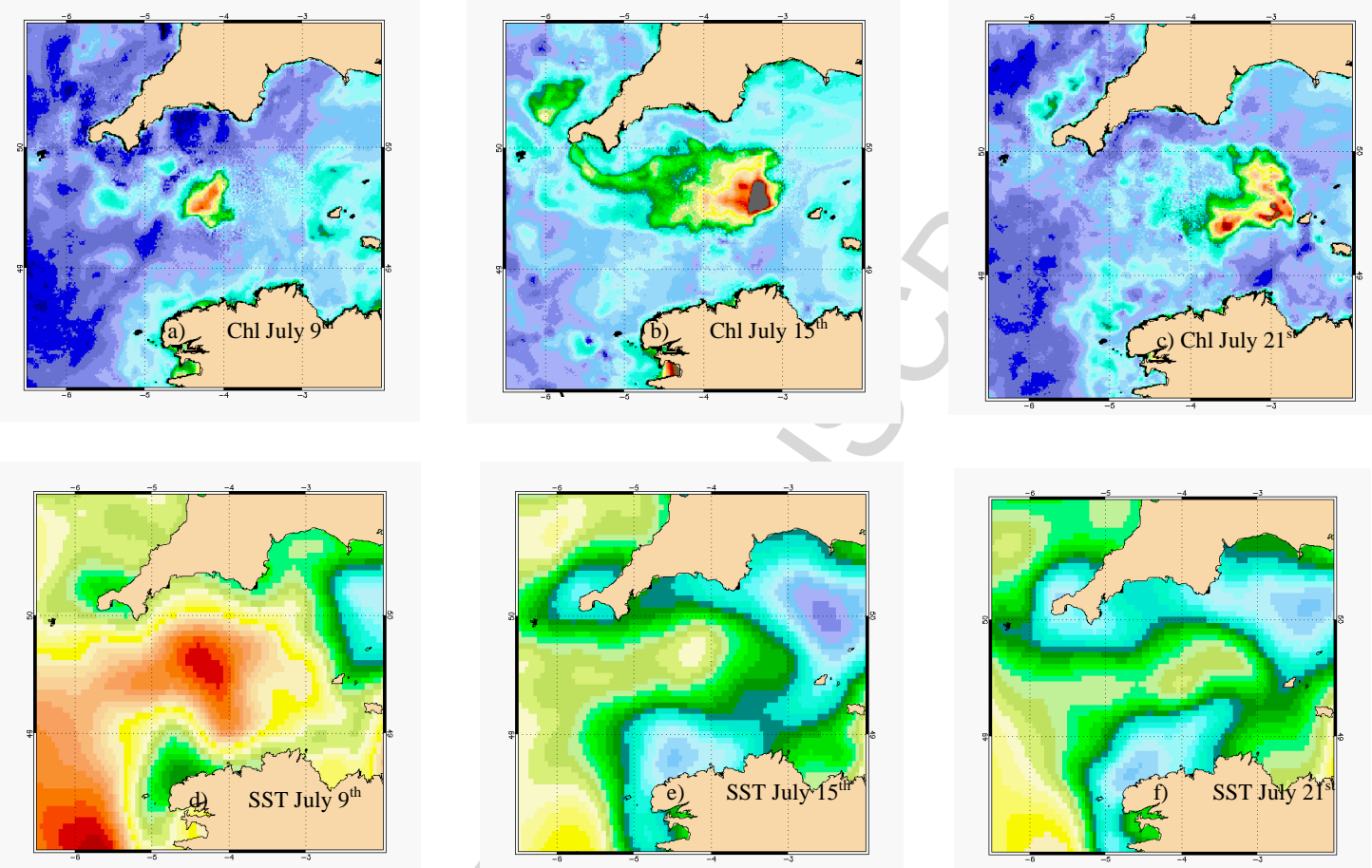

Fig. 3: Satellite-derived Chl-a and Sea Surface Temperature on $9^{\text {th }}$ July, (a) and (d), $15^{\text {th }}$ July, (b) and (e), and $21^{\text {st }}$ July 2010, (c) and (f). Chl-a maps are merged MERIS/MODIS OC5 Ifremer products and SST are merged OSTIA/UK Met Office products 


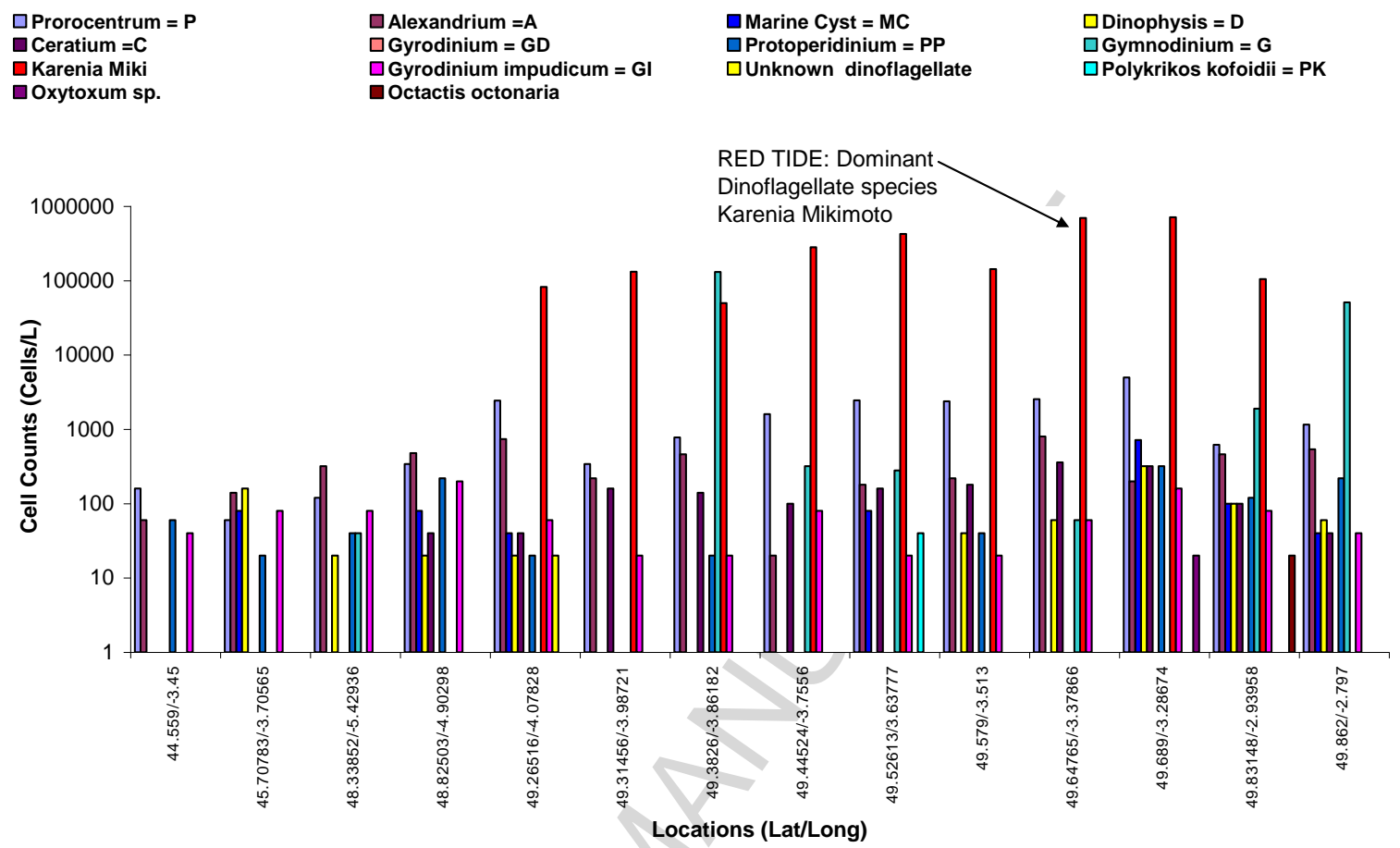

Fig. 4: Cell counts (per Litre) plotted on a log scale for a single crossing from Portsmouth to Bilbao, Spain (12-15 th July 2010). The position of each sample is shown on the $\mathrm{x}$-axis (as latitude/longitude).

a)

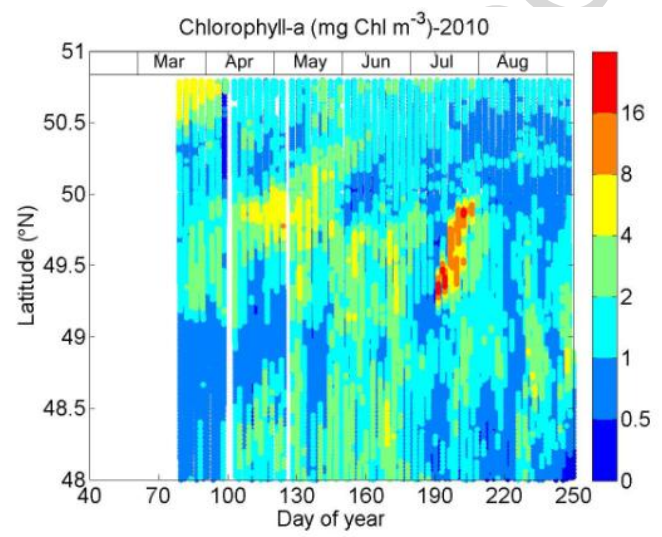

b)

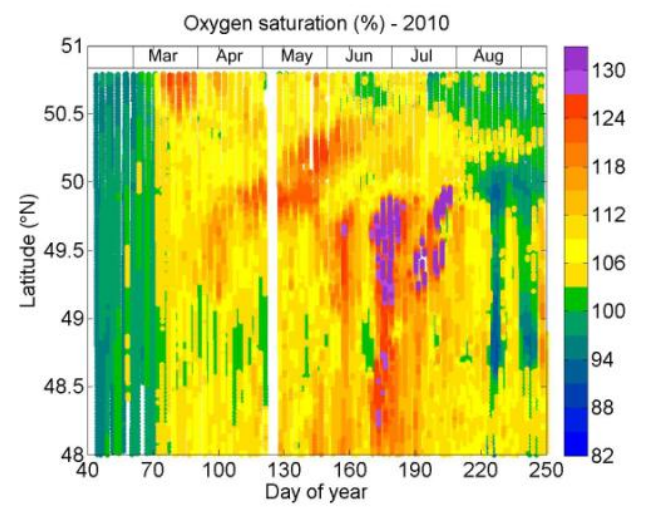


c)

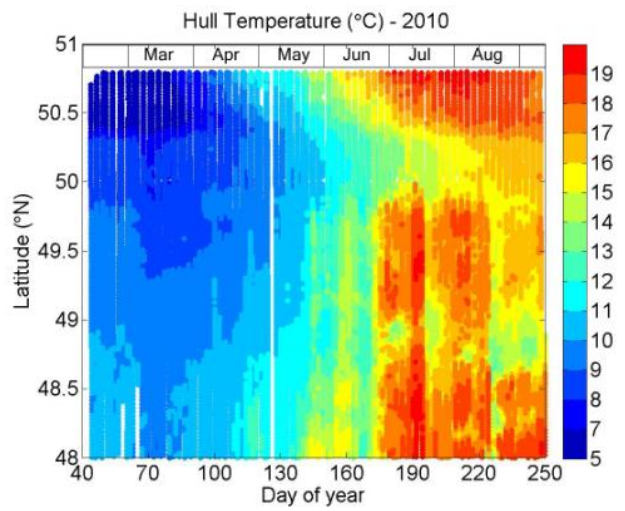

d)

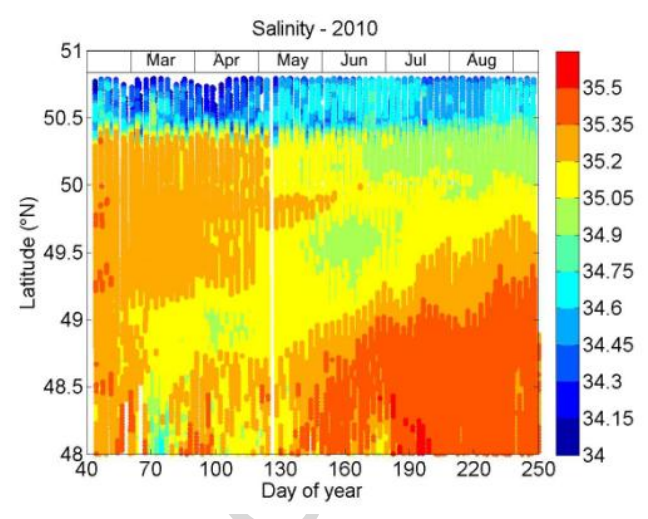

Fig. 5: Hovmöller plot showing temporal and spatial variability in the Ferry-box variables between Ushant $\left(48^{\circ} \mathrm{N}\right)$ and Portsmouth $\left(51^{\circ} \mathrm{N}\right)$ from day $40\left(9^{\text {th }} \mathrm{Feb}\right)$ to day 250 ( $7^{\text {th }}$ Sep), 2010: a) chlorophyll; b) oxygen saturation; c) temperature; d) salinity.

a)

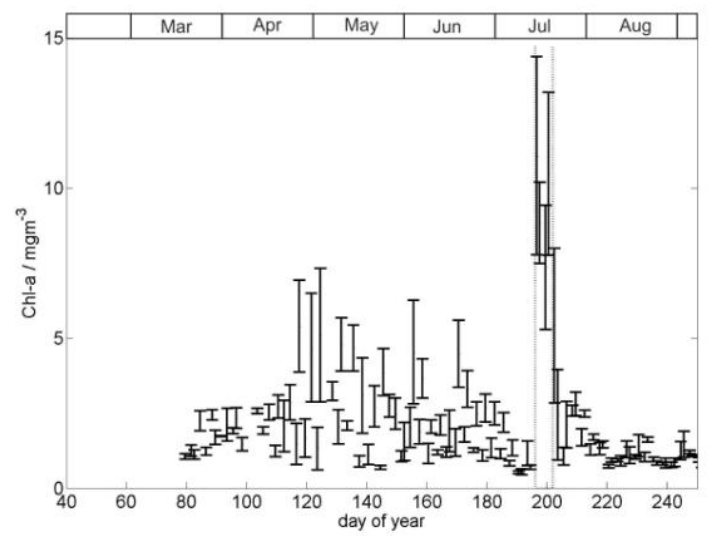

c)

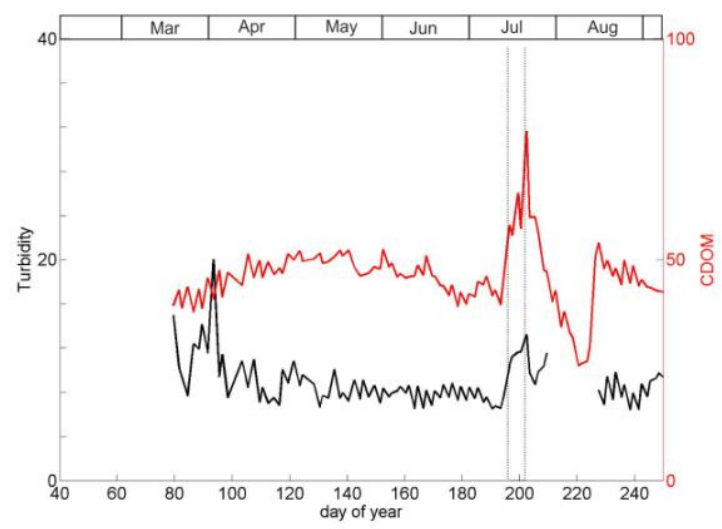

b)

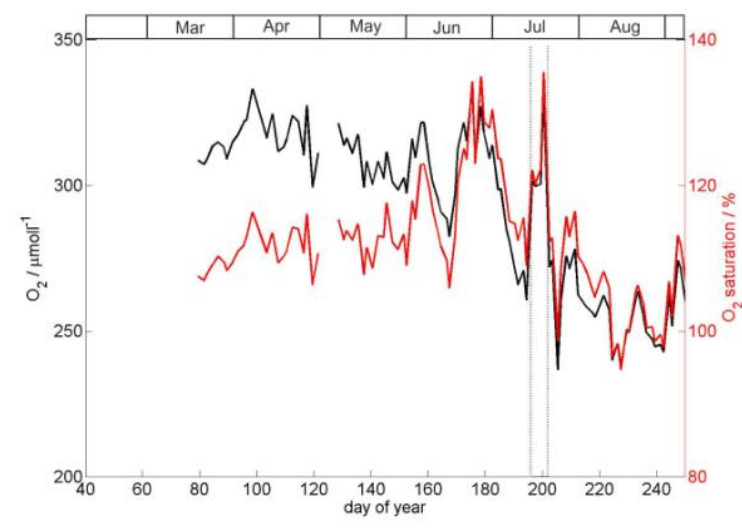

d)

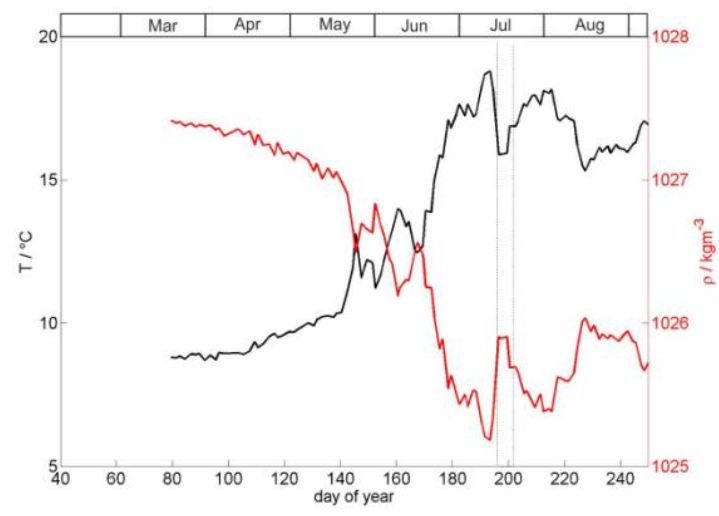


e)

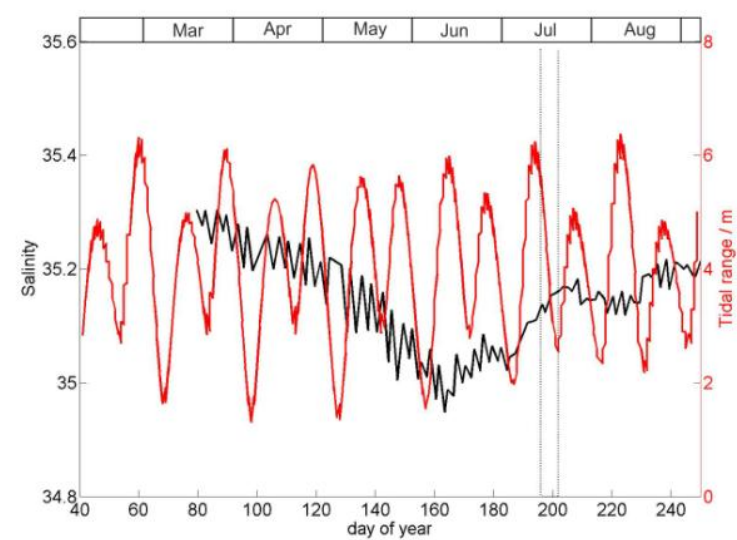

f)

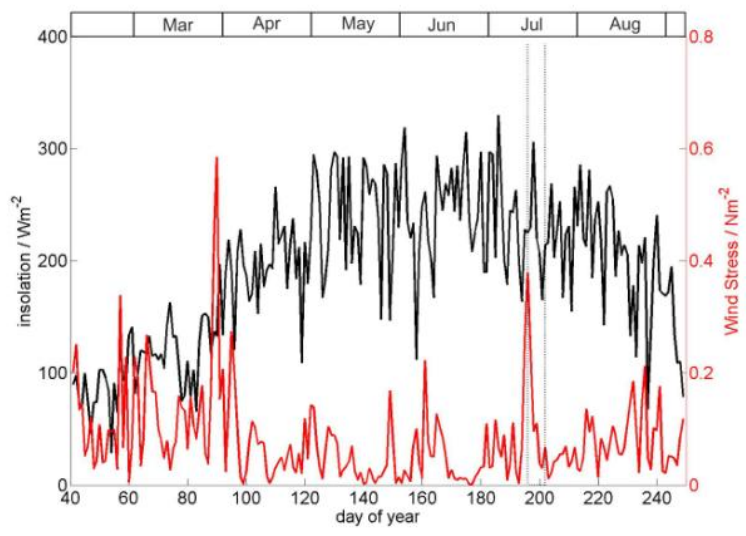

Fig. 6: a) Chlorophyll at $49.7^{\circ} \mathrm{N}$ (extracted time series from the Ferry-box data set) showing the mean +/- 1 standard deviation for each day; $b$ ) Ferry-box dissolved oxygen (black) and oxygen saturation (red); c) Ferry-box turbidity (black) and coloured dissolved organic material (CDOM) (red); d) Ferry-box temperature (black) data and density (red), calculated from salinity and temperature data from the ferry; e) Ferry-box salinity (black) data and Tidal range from model data (red); $f$ ) Solar radiation (black) and wind stress magnitude (red) NCEP data. The dotted lines denote the peak of the Karenia mikimotoi bloom around day 196, $15^{\text {th }}$ July 2010.

a)

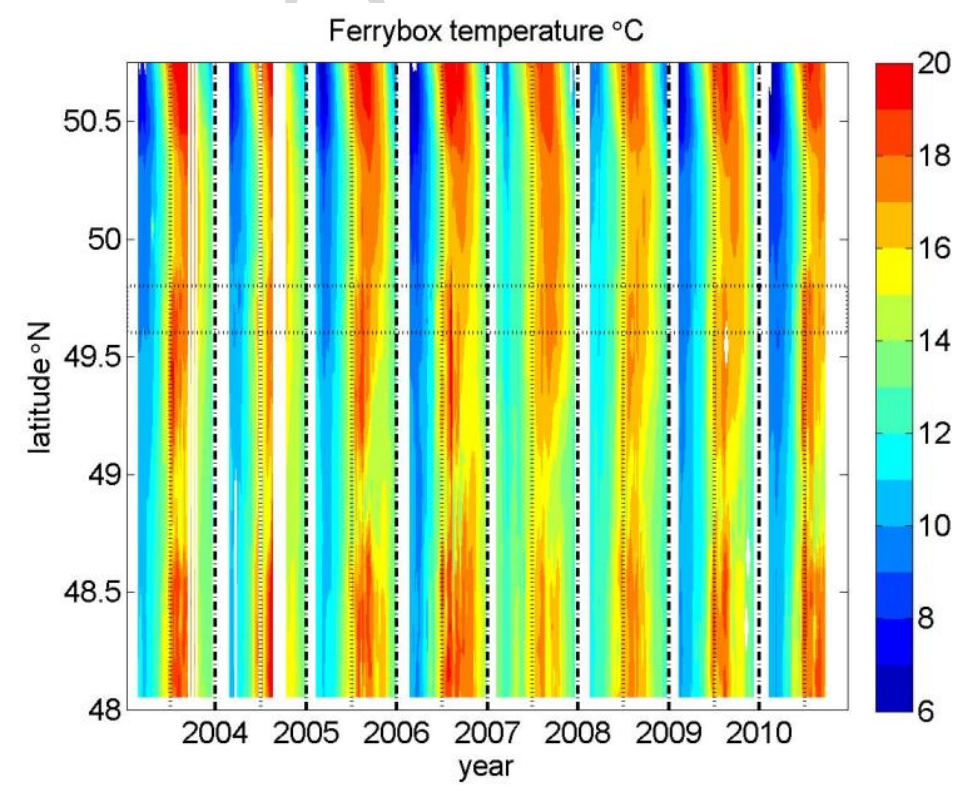


c)
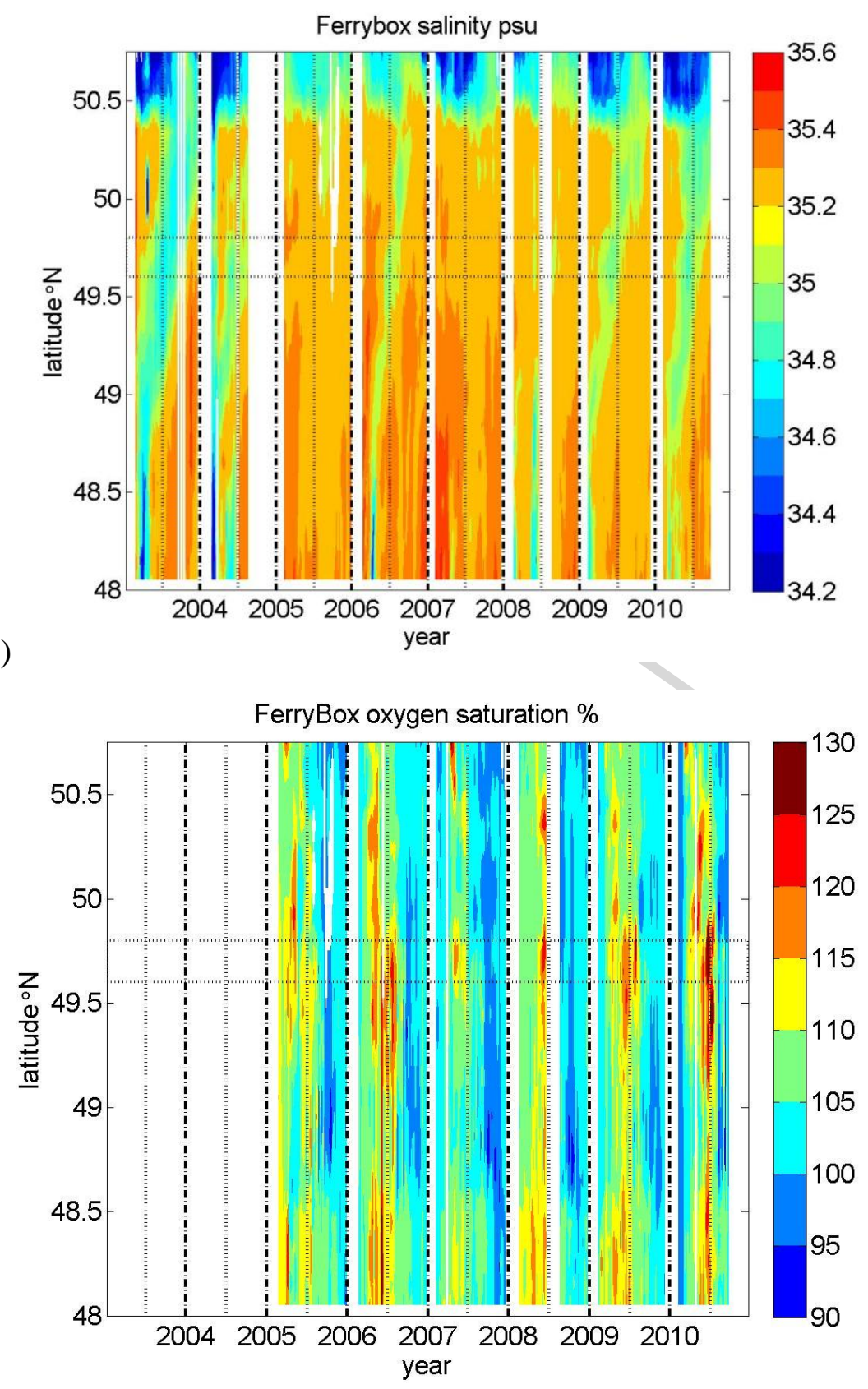

Fig. 7: Hovmöller plots to show the spatial and temporal variability of a) temperature, b) salinity and c) oxygen saturation on repeat ferry tracks north of $48^{\circ} \mathrm{N}$ from 2003 to 2010 (horizontal dotted lines mark the area selected for a time series at $49.7^{\circ} \mathrm{N}$ and the vertical dotted lines show the start of January and July for each year). 


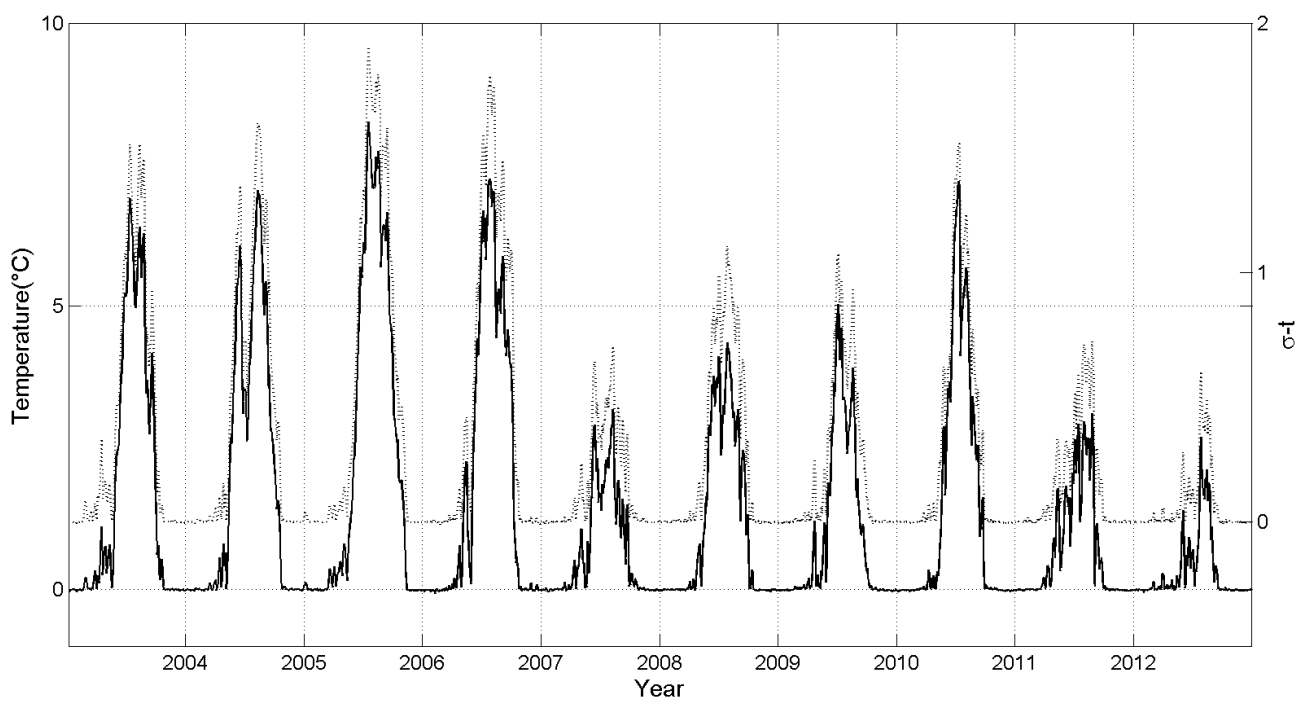

Fig. 8: Results from a 3D hindcast model (Lazure et al., 2009) in the Western English Channel, off Roscoff $\left(49.5^{\circ} \mathrm{N}, 4^{\circ} \mathrm{W}\right)$, from 2003 to 2012 . The difference between surface and bottom temperature (black line) and the difference in density (grey line) are shown as an indicator of stratification.

\section{References}

Bargeron, C.P., Hydes, D.J., Woolf, D.K., Kelly-Gerreyn, B.A., Qurban, M., 2006. A regional analysis of new production on the northwest European shelf using oxygen fluxes and a ship of opportunity. Estuarine and Coastal Shelf Science, 69, (3-4), 478490.

Behrenfield, M.J., O’Malley, R.T., Siegel, D.A., 2006. Climate-driven trends in contemporary ocean productivity. Nature, 444, 752-755.

Blondeau-Patissier, D., Tilstone, G.H., Martinez-Vicente, V., Moore, G.F., 2004. Comparison of bio-physical marine products from SeaWiFS, MODIS and a bio-optical model with in situ measurements from Northern European waters. Journal of Optics A: Pure and Applied Optics, 6, 875-889.

Brand, L.E., Campbell, L, Bresnan, E., 2012. Karenia: The biology and ecology of a toxic genus. Harmful algae, 14, 156-178.

Davidson, K., Miller, P., Wilding, T., Shutler, J., Bresnan, E., Kennington, K., Swan, S., 2009. A large and prolonged bloom of Karenia mikimotoi in Scottish waters in 2006. 
Harmful Algae, 8, 349-361.

Dahl, E., Tangen, K., 1993. 25 Years experience with Gyrodinium aureolum in Norwegian waters. In Toxic Phytoplankton Blooms in the Sea. (ed. T. J. Smayda and Y. Shimizu), pp. 15-22.

Falkowski, P., Kiefer, D.A., 1985. Chlorophyll a fluorescence in phytoplankton: relationship to photosynthesis and biomass. Journal of Plankton Research, 7, 715-731.

Falkowski, P.J., Oliver, M.J., 2007. Mix and match: how climate selects phytoplankton. Nature Rev. Microbiol., 5, 813-819.

Fu, F. X., Tatters, A. O., Hutchins, D. A., 2012. Global change and the future of harmful algal blooms in the ocean. Mar Ecol Prog Ser., 470, 207-233.

Garcia-Soto, C, Pingree, R.D., 2009. Spring and summer blooms of phytoplankton (SeaWiFS/MODIS) along a ferry line in the Bay of Biscay and western English Channel. Continental Shelf Science, 29 (8), 1111-1122.

Gentien, P., 1998. Bloom dynamics and ecophysiology of the Gymnodinium mikimotoi species complex. In: Anderson,D. M., Cembella, A. D.Hallegraeff, G. M. (Eds), Physiological ecology of harmful algal blooms, Vol G 41. Springer-Verlag, Berlin, pp 155-173.

Gentien, P., Lunven, M., Lazure, P., Youenou, A., Crassous, M.P., 2007. Motility and autotoxicity in Karenia mikimotoi (Dinophyceae). Philos. Trans. R. Soc. B, 362, 1937-1946.

Gohin, F., Le-Bec, C., Cutting, J., 2010. Note on the real-time time detection of a Karenia mikimotoi bloom from space in the Western English Channel in July 2010 in: MarCoast2 quarterly report 3. http://archimer.ifremer.fr/doc/00178/28883/

Gollop, M.A., Raitsos, D.E, Edwards, M., Pradhan, Y., Mee, L., Lavender, S., Attrill, M., 2007. A long-term chlorophyll dataset reveals regime shift in North Sea phytoplankton biomass unconnected to nutrient levels. Limnol. Oceanogr., 52, 635648.

Gómez, G, Souissi, S., 2008. The impact of the 2003 summer heat wave and the 2005 late cold wave on the phytoplankton in the north-eastern English Channel. C. R. Biologies, 331, 678-685.

Gowen, R.J, Tett, P., Kennington, K., Mills, D.K., Shammon, T.M., Stewart, B.M., Greenwood, N., Flanagan, C., Devlin, M., Wither, A., 2008. The Irish Sea: Is it eutrophic? Estuarine and Coastal Shelf Science, 76 (2), 239-254. 
Hartman, S.E., Hartman, M.C., Hydes, D.J., Jiang, Z.P., Smythe-Wright, D., González-Pola, C., 2013. Seasonal and inter-annual variability in nutrient supply in relation to mixing in the Bay of Biscay. Deep Sea Research Part II: Topical Studies in Oceanography (in press).

Holley, S.E., Hydes, D.J, 2002. Ferry-Boxes and data stations for improved monitoring and resolution of eutrophication-related processes: application in Southampton Water UK, a temperate latitude hypernutrified estuary. Hydrobiologia, 475/476, 99-110.

Holligan, P.M., Viollier, M., Dupouy, C., Aiken, J., 1983. Satellite studies on the distributions of chlorophyll and dinoflagellate blooms in the western English-channel. Continental Shelf Research, 2 (2-3), 81-96.

Holligan, P.M., Williams, P.J.le B., Purdie, D., Harris, R.P., 1984. Photosynthesis, respiration and nitrogen supply of plankton populations in stratified, frontal and tidally mixed shelf waters. Mar. Ecol. Prog. Ser., 17, 201-213.

Hydes, D.J., Yool, A., Campbell, J.M., Crisp, N.A., Dodgson, J., Dupee, B., Edwards, M., Hartman, S.E., Kelly-Gerreyn, B.A., Lavin, A.M., Gonzalez-Pola, C.M., Miller, P., 2003. Use of a Ferry-Box system to look at shelf sea and ocean margin processes. Elvevier Oceanography Series, Building the European Capacity in Operational Oceanography, 69, 297-303.

Hydes, D.J., Hartman, M.C., Bargeron, C.P., Campbell, J.M., Curé, M.S., Woolf, D.K., 2008. A study of gas exchange during the transition from deep winter mixing to spring bloom in the Bay of Biscay measured by continuous observation from a ship of opportunity. Journal of Operational Oceanography, 1(2), 41-50.

Irigoien, X., Meyer, B., Harris, R., Harbour, D., 2004. Using HPLC pigment analysis to investigate phytoplankton Taxonomy: The importance of knowing your species. Helgol Mar Res, 58, 77-82.

Jordan, M.B., Joint, I.R., 1984. Studies on phytoplankton distribution and primary production in the western English Channel in 1980 and 1981. Continental Shelf Research, 3(1), 25-34.

Josey, S.A., Kent, E.C., Taylor, P.K., 2002. Wind Stress Forcing of the Ocean in the SOC Climatology: Comparisons with the NCEP-NCAR, ECMWF, UWM/COADS, and Hellerman and Rosenstein Datasets. Journal of Physical Oceanography, 32(7), 19932019.

Kelly-Gerreyn, B.A., Hydes, D.J., Jégou, A.M., Lazure, P., Fernand, L.J., Puillat, I., García 
Soto, C., 2006. Low salinity intrusions in the western English Channel Continental Shelf Research, 26 (11), 1241-1257.

Lazure, P., Garnier V., Dumas F., Herry C., Chifflet M., 2009. Development of a hydrodynamic model of the Bay of Biscay. Validation of hydrology. Cont. Shelf. Res., doi: 10.1016/j.csr.2008.12.017

Le Corre, P., L'Helguen, S., Wafar, M., 1993. Nitrogen source for uptake by Gyrodinium cf. aureolum in a tidal front. Limnol. Oceanogr., 38, 446-451.

Lindahl, O., 1993. Hydrodynamic processes: A trigger and source for flagellate blooms along the Skagerrak coasts? In: Smayda, T. J.Shimizu, Y.(Eds), Toxic phytoplankton in the sea. Elsevier Science Publishers, 775-782.

Morin, P., Birrien, J. L., Le Corre, P., 1989. The frontal systems in the Iroise Sea:

Development of Gyrodinium aureolum Hulburt on the inner front. Sci. Mar., 53, 215221.

Petihakis, G., Drakopoulos, P., Nittis, C., Zervakis, V., Christodoulou, C., Tziavos , C., 2007. M3A system (2000-2005) - operation and maintenance. Ocean Science, 3(1), 117128.

Pingree, R.D., Pugh, P.R., Holligan, P.M., Forster, G.R., 1975. Summer phytoplankton blooms and red tides along tidal fronts in approaches to English-channel. Nature, 258, 672-677.

Pingree, R.D., Holligan, P.M., Head, R.N., 1977. Survival of dinoflagellate blooms in the western English Channel. Nature, 265, 266-269.

Pingree, R.D., Griffiths, D.K., 1978. Tidal fronts on the shelf seas around the British Isles. Journal of Geophysical Research, 83, 4615-4622.

Pingree, R.D., 1980. Physical oceanography of the Celtic Sea and English Channel. In: Banner, F. T., Collins, M. B., Massie, K. S. (Eds), The north-west European shelf seas: The seabed and the sea in motion 2. Physical and chemical oceanography and physical resources. Elsevier, New York, pp 638.

Purina, I., Balode, M., Béchemin, C., Põder, T, Vérité, C., Maestrini, S., 2004. Influence of dissolved organic matter from terrestrial origin on the changes of dinoflagellate species composition in the Gulf of Riga, Baltic Sea. Hydrobiologia, 514, 127-137.

Qurban, M.A., 2009. An investigation of factors influencing the spatial and temporal distribution of surface phytoplankton in the English Channel and Bay of Biscay in 2003 and 2004. PhD thesis, University of Southampton. 
Raine, R., O’Boyle, S.,O’Higgins, T., White, M., Patching, J.,Cahill, B., McMahon T., 2001. A satellite and field portrait of a Karenia mikimotoi bloom off the south coast of Ireland, August 1998. Hydrobiologia, 465, 187-193.

Ross, O. N., Sharples, J., 2007. Phytoplankton motility and the competition for nutrients in the thermocline. Mar. Ecol. Prog. Ser., 347, 21-38.

Satake, M., Tanaka, Y., Ishikura, Y., Oshima, Y., Naoki, H., Yasumoto, T., 2005. Gymnocin$\mathrm{B}$ with the largest contiguous polyether rings from the red tide dinoflagellate, Karenia (formerly Gymnodinium) mikimotoi. Tetrahedron Lett., 46, 3537-3540.

Sharples, J., Moore, C.M., Rippeth, T.P., Holligan, P.M., Hydes, D., Fisher, N.R., Simpson, J.H., 2005. Phytoplankton survival in the thermocline. Limnol.Oceanogr., 46, 486496.

Sharples, J., 2008. Potential impacts of the spring-neap tidal cycle on shelf sea primary production. J. Plankton Res., 30 (2), 183-197.

Silke, J., O’Beirn, F., Cronin M., 2005. Karenia : an exceptional dinoflagellate bloom in western Irish waters summer 2005. Marine Environment and health Series, 21, Marine Institute, Galway, Ireland. Available on line at www.marine.ie

Smayda, T., 1997. Harmful algal blooms: Their ecophysiology and general relevance to phytoplankton blooms in the sea, Limnol. Oceanogr., 42(5), 1137-1153.

Smayda TJ., 2002. Adaptive ecology, growth strategies and the global bloom expansion of dinoflagellates. Journal of Oceanography, 58, 281-294.

Smyth, T.J., Fishwick, J.R., Moosawi, L., Cummings, D.G., Harris, C., Kitidis, V., Rees, A., Martinez-Vicente, V., Woodward, E.M.S., 2010. A broad spatio-temporal view of the Western English Channel observatory. Journal of Plankton Research, 32, (5), 585601.

Smythe-Wright, D., Daniel, A., Boswell, S., Purcell, D., Hartman, M., Hartman, S., Hydes, D., 2014. Phytoplankton and pigment studies in the Bay of Biscay and English Channel. Deep Sea Research Part II: Topical Studies in Oceanography (in press).

Suggett, D.J., MacIntyre, H.L., Geider, R.J., 2004. Evaluation of biophysical and optical determinations of light absorption by photosystem II in phytoplankton. Limnol. Oceanogr Methods, 2, 316-332.

Tangen, K., 1977. Blooms of Gyrodinium aureolum (Dinophyceae) in north European waters, accompanied by mortality in marine organisms. Sarsia, 63, 123-133. 
Ulrich, R.M., Casper, E.T., Campbell, L., Richardson, B., Heil, C.A., Paul, J.H., 2010. Detection and quantification of Karenia mikimotoi using real-time nucleic acid sequence-based amplification with internal control RNA (IC-NASBA). Harmful Algae, 9, 116-122.

UNESCO, 1983. Algorithms for computation of fundamental properties of seawater, 1983. UNESCO Technical Paper in Marine Science, 44, 53.

Uye, S., Takamatsu, K., 1990. Feeding interactions between planktonic copepods and red-tide flagellates from Japanese coastal waters. Mar. Ecol. Prog. Ser., 59, 97-107.

Vanhoutte-Brunier, A., Fernand, L., Ménesguen, A., Lyons, S., Gohin, F., Cugier, P., 2008. Modelling the Karenia mikimotoi bloom that occurred in the western English Channel during summer 2003. Ecological Modelling, 210, 351-376.

Videau, C., Ryckaert, M., L’Helguen., S., 1998. Phytoplankton in the Bay of Seine (France): influence of the river plume on primary productivity. Oceanol Acta, 21, 907-921 (in French with English abstract).

Widdicombe, C.E., Eloire, D., Harbour, D., Harris, R.P., Somerfield, P.J., 2010. Long-term phytoplankton community dynamics in the Western English Channel. Journal of Plankton Research, 32(5), 643-655. 